УДК: 351:347.132.15

\author{
Бєлікова Ксенія, \\ канд. техн. наук, \\ старш. наук. співроб. \\ ORCID iD 0000-0001-7475-2115 \\ E-mail: acutus@ukr.net \\ Кравченко Юлія, \\ канд. економ. наук \\ ORCID iD 0000-0002-3709-7016 \\ E-mail: kravchenko-yulia@ukr.net \\ Потеряйко Сергій, \\ канд. військ. наук, доц., \\ ORCID iD 0000-0002-3787-0929 \\ E-mail: sergiy_kiev@ukr.net \\ Марченко Олександр, \\ канд. військ. наук, доц., \\ ORCID iD 0000-0002-5189-3254 \\ E-mail: martcello@i.ua
}

\title{
ОРГАНІЗАЦІЯ ВЗАЕМОДІЇ МІЖ ОРГАНАМИ УПРАВЛІННЯ У НАДЗВИЧАЙНИХ СИТУАЦІЯХ: ПРАВОВИЙ, ОРГАНІЗАЦІЙНИЙ ТА ЕКОНОМІЧНИЙ АСПЕКТИ
}

https://doi.org/10.32689/2618-0065-2020-4(6)-6-29

\begin{abstract}
Анотація. Значна кількість надзвичайних ситуацій, що відбуваються в світі, їх місцями масштабні наслідки та безповоротні втрати змушують науковців дедалі частіше сферою своїх наукових інтересів обирати дослідження причин виникнення непередбачуваних подій з метою їх попереджень, особливостей реагування на них відповідних служб, ефективності ліквідації наслідків надзвичайних ситуацій як природного, так і техногенного характеру тощо. Окремої уваги заслуговує побудова раціональної взаємодії між органами управління та силами, що залучаються до ліквідації наслідків надзвичайних ситуацій. Адже, від
\end{abstract}




\section{Науковий вісник: Державне управління № 4(6)2020}

злагодженості такої взаємодії, вчасного коригування дій цих органів та сил на підставі релевантної інформації залежить життя людей. Враховуючи зазначене, авторським колективом досліджено актуальні правові, організаційні та економічні аспекти щодо організації взаємодії між органами управління в умовах надзвичайних ситуацій. На підставі отриманих наукових результатів, запропоновано заходи щодо удосконалення процесу організації взаємодії, зокрема: правового забезпечення - шляхом внесення доповнень в Кодекс цивільного захисту України щодо заходів взаємодії, організаційного - шляхом визначення раціонального методу організації взаємодії, що відповідає умовам конкретної надзвичайної ситуації, економічного - застосування раціонального методу фінансово-економічного аналізу, що дозволяє визначити найбільш ефективний, результативний та економічний метод взаємодії.

Ключові слова: надзвичайна ситуація, методи взаємодії, органи управління, економічне обгрунтування, управлінське рішення, фінансово-економічний аналіз.

Постановка проблеми. Динаміка змін в стані природнотехногенної безпеки в країні за останні роки, на жаль, свідчить про збільшення масштабності наслідків надзвичайних ситуацій, зокрема кількості загиблих та постраждалих та матеріальних збитків, що понесла держава загалом, i громадяни України - зокрема. Зазначене підтверджує висновки, що під час реагування на надзвичайні ситуації мають місце недоліки в організації управління у надзвичайних ситуаціях, прийнятті своєчасних i адекватних оперативній обстановці рішень, організації взаємодії між силами, що залучаються до реагування на надзвичайні ситуації, а також в проведенні аварійно-рятувальних та інших невідкладних робіт, що свідчить про поверхневе відношення керівників органів управління до важливого етапу управлінського процесу організації та підтримання взаємодії.

У зв'язку із зазначеним наразі актуальним питанням є пошук шляхів удосконалення правового, організаційного та економічного аспектів щодо організації взаємодії між органами управління у надзвичайних ситуаціях. 
Науковий вісник: Державне управління № 4(6)2020

\section{Аналіз останніх досліджень і публікацій.}

Дослідженню проблемних питань державного управління загалом, та державного управління у сфері цивільного захисту - зокрема, присвячено низку наукових праць.

Питання організації взаємодії $\epsilon$ складовою частиною прийняття рішення керівником органу управління. Зважаючи на зазначене, вважаємо вагомими результатами досліджень наукові здобутки засновника науки державного управління В. Бакуменка, який науково-теоретично обгрунтував засади формування державно-управлінських рішень і визначив шляхи застосування отриманих наукових результатів у практиці державного управління в Україні [1]. Автор вважає, що існує низка чинників впливу суспільних трансформацій на ефективність i результативність державного управління, зокрема, функціональний чинник, що пов'язаний 3 технологіями управління, інформаційний чинник, що пов'язаний із забезпеченням державно-управлінського процесу необхідною та достатньою інформацією. Порушення цієї умови може привести до нераціональних державноуправлінських рішень. Однією 3 найбільш поширених технологій управління, на думку вченого, $\epsilon$ раціональна модель прийняття рішень, що передбачає виявлення i діагностування проблеми, формулювання обмежень і критеріїв для прийняття рішень, визначення альтернатив, їх оцінювання, вибір найкращої з альтернатив [1].

Отже, на організацію взаємодії, що здійснюється в процесі здійснення управління, впливають технології управління (методи, засоби, способи), альтернативи методів організації взаємодії, інформаційне забезпечення зазначеного процесу. Вважаємо, що, зважаючи на загальні обставини в економіці України, на управління загалом, і взаємодію - зокрема суттєво впливає економічний чинник.

У сфері цивільного захисту привертають увагу результати досліджень П. Волянського, який узагальнив досвід спільної роботи аварійно-рятувальних підрозділів у складі 
міжнародних спільних гуманітарних операцій. Автор вважає, що узгодження спільних цивільний та військових дій, взаємної підтримки здійснюється за умови, насамперед, обміну інформацією, об'єднаного планування та спільного оцінювання ситуації, що склалась, проведення спільних нарад, перемовин тощо. Отже, вважає вчений, ключовим моментом взаємодії у зазначених умовах $є$ обмін інформацією, а основоположним організаційним принципом взаємодії має бути система зв'язків між рівнями реагування, що створені на єдиній інформаційно-аналітичній системі [2].

Основні завдання управління в умовах надзвичайних ситуацій визначила А. Терент'єва, зокрема: підтримання високого ступеню готовності до дій сил цивільного захисту, планування заходів, постійний збір та вивчення даних про обставини в районі надзвичайної ситуації, оперативне прийняття рішень та їх доведення до підпорядкованих органів управління, організація та забезпечення безперервної взаємодії, проведення аварійно-рятувальних та інших невідкладних робіт, організація всебічного забезпечення сил i засобів, контроль виконання завдань [3].

Зарубіжні вчені Син Чанвон, Фарзан Сасангохар, Тімоті Дж. Невіл, С. Каміль Пер, Жукрін Мун зазначають, що адаптовані до роботи в складних умовах команди з управління інцидентами повинні діяти стійко, оскільки надзвичайні ситуації розвиваються несподівано. Не зважаючи на те, що стійкість в управлінні надзвичайними ситуаціями широко вивчалася в багатьох контекстах надзвичайних ситуацій, розробка нового методу дослідження фактичної стійкості управління інцидентами в реальних умовах була недовершеною. 3 метою усунення зазначеного недоліку авторами вперше введено аналіз епізодів взаємодії, що передбачає новий підхід до фіксації та опису результативності командної роботи [4].

О. Дерев'янко, В. Юрченко також приділили увагу питанням організації взаємодії. В своїй роботі автори 
розглянули питання щодо організації взаємодії між органами управління та силами цивільного захисту як ключове питання управління у надзвичайних ситуаціях. Вчені вважають, що в переліку оперативно-технічної та звітної документації штабу з ліквідації наслідків надзвичайних ситуацій обов'язково повинен бути План взаємодії між органами управління та силами цивільного захисту як окремий документ по установленій формі у відповідності до завдань, які відпрацьовуються під час організації взаємодії. Автори запропонували керівникам органів влади різних рівнів управління, суб'єктів господарювання під час планування проведення різних видів навчань особливу увагу звернути на відпрацювання питань організації взаємодії між органами управління та силами цивільного захисту у надзвичайних ситуаціях 3 постійним удосконаленням методів організації взаємодії [5].

Ю. Кульшай, В. Юрченко вважають, що існуючі загрози і виклики суспільству обумовлені великими масштабами їх наслідків, для ліквідації яких потрібні зосередження зусиль усіх органів влади, організації взаємодії різних органів управління, сил і засобів цивільного захисту. 3 метою якісного вирішення питань щодо ліквідація наслідків надзвичайних ситуацій вимагає системного підходу до координованості дій та організації взаємодії між усіма структурними підрозділами центральних і місцевих органів виконавчої влади, органів місцевого самоврядування та силами цивільного захисту. Автори запропонували посадовим особам органів управління завчасно та в ході виконання завдань за призначенням відпрацьовувати та уточнювати плани взаємодії між органами управління та силами цивільного захисту функціональних і територіальних підсистем, їх ланок під час ліквідації наслідків конкретних надзвичайних ситуацій. Під час розробки зазначених планів передбачати чітке розмежування повноважень між учасниками забезпечення системи цивільного захисту, а в ході проведення командно-штабних 
Науковий вісник: Державне управління № 4(6)2020

навчань планувати розіграш сценаріїв виникнення надзвичайних ситуацій та застосування раціональних методів організації взаємодії [6].

О. Кулєшов виявив низку проблемних питань, пов'язаних 3 організацією взаємоузгоджених дій суб'єктів цивільного захисту під час виконання завдань за призначенням, зокрема, щодо розуміння самої суті взаємодії як однієї із форм управління. Інше проблемне питання, що порушено автором, пов'язане 3 невизначеністю змісту взаємодії, що унеможливлює чітко спланувати і реалізувати сумісні дії взаємодіючих служб цивільного захисту [7].

Отже, питанню організації взаємодії між органами управління та силами цивільного захисту під час ліквідації наслідків надзвичайних ситуацій присвячено публікації багатьох вітчизняних фахівців та науковців. Але, при всій глибині проведених досліджень, недостатньо дослідженими залишаються проблемні питання щодо удосконалення правового, організаційного та економічного забезпечення організації взаємодії між органами управління в умовах надзвичайних ситуацій.

Постановка завдання. На підставі результатів попередніх наукових досліджень, досвіду діяльності органів управління та сил цивільного захисту розробити пропозиції щодо удосконалення правового, організаційного та економічного забезпечення процесу організації взаємодії між органами управління в умовах надзвичайних ситуацій.

Виклад основного матеріалу. Аналіз дій органів управління та сил цивільного захисту у надзвичайних ситуаціях протягом 2019 року свідчить про те, що у деяких заходах частково відпрацьовувалися питання організації взаємодії між органами управління та підрозділами цивільного захисту, що не являли собою системного характеру.

Так, упродовж 2019 року органами та формуваннями ДСНС забезпечено оперативне реагування на 146 класифікованих надзвичайних ситуацій, які за масштабами 
розподілилися на державного рівня - 2, регіонального - 7, місцевого - 63, об’єктового - 74, внаслідок яких загинуло 199 осіб та постраждало 1 тис. 492 особи [8].

Під час реагування на зазначені надзвичайні ситуації територіальні органи управління та підрозділи ДСНС України разом із центральними та місцевими органами виконавчої влади забезпечено виконання спільних завдань в умовах надзвичайних ситуацій, зокрема, налагоджено чітку взаємодію 3 Укравтодором, Нацполіцією, Укртрансбезпекою. Забезпечено участь представників ДСНС у роботі Штабу 3 ліквідації наслідків надзвичайної ситуації. Своєчасно вжиті заходи дозволили не допустити загибелі людей та надати необхідну допомогу населенню [8].

Також представники ДСНС взяли участь у роботі Міжвідомчого оперативного штабу 3 ліквідації наслідків надзвичайної ситуації у період пропуску весняної повені, де, зокрема, відпрацьовувалися питання організації міжвідомчої взаємодії. Протягом 2019 року ДСНС організовано та проведено: спеціальне навчання щодо демонстрації можливостей пожежно-рятувальних сил під час проведення операцій з ліквідації наслідків надзвичайних ситуацій на базі полігона Мобільного рятувального центру швидкого реагування, навчання в рамках переатестації пошуковорятувальної команди важкого класу Мобільного рятувального центру швидкого реагування ДСНС у системі Міжнародної консультативної групи ОOH - INSARAG, тактико-спеціальні навчання щодо організації взаємодії між органами управління системи МВС під час спільного виконання завдань наземних та авіаційних сил ДСНС щодо гасіння пожеж, командноштабні навчання 3 питань організації реагування органів управління та сил цивільного захисту на загрози осінньозимового періоду із залученням керівного складу МВС, ДСНС, Мінрегіону, Мінекоенерго, Мінсоцполітики, MO3, Мінінфраструктури, Укравтодору, Укртрансбезпеки, Нацполіції та обласних і Київської міської держадміністрацій, 
відпрацьовано порядок організації та проведення аеромедичної евакуації постраждалого особового складу ДСНС, МВС, Нацполіції, Держприкордонслужби, Нацгвардії повітряними суднами ДСНС у медичному варіанті. Крім того, у рамках проєкту "Посилення потенціалу України у сфері цивільного захисту II" ДСНС у 2019 році на базі Інституту державного управління та наукових досліджень з цивільного захисту за участі представників Академії кризового управління, планування на випадок надзвичайних ситуацій та цивільного захисту (AKNZ) Федерального відомства у справах захисту населення та допомоги при катастрофах ФРН (ВВК) проведено цикл тренінгів та штабне навчання 3 питань кризового управління у разі виникнення надзвичайних ситуацій iз залученням представників закладів освіти ДСНС, обласних та Київської міської державних адміністрацій, навчальнометодичних центрів сфери цивільного захисту та Адміністрації Держприкордонслужби [8].

Під час виконання зазначених завдань відпрацьовувались, зокрема, питання щодо організації взаємодії між структурами, що брали участь у вказаних заходах, однак, окремим етапом навчань, заходів зазначені питання не було винесено.

Аналіз змісту законодавства із зазначеного питання свідчить про те, що в їхніх основних положеннях частково окреслено питання щодо організації взаємодії. Зокрема, постановою Кабінету Міністрів України від 9 січня 2014 р. № 11 "Про затвердження Положення про єдину державну систему цивільного захисту”, ст. 32 визначено, що 3 метою організації взаємодії між органами управління та силами цивільного захисту функціональних і територіальних підсистем, їх ланок під час ліквідації наслідків конкретних надзвичайних ситуацій зазначеними органами та силами відпрацьовуються плани такої взаємодії [9]. У постанові Кабінету Міністрів України від 14 березня 2018 р. № 223 “Про затвердження Плану реагування на надзвичайні ситуації державного рівня" у ст. 41 здійснюється посилання на те, що 
Науковий вісник: Державне управління № 4(6)2020

органи управління цивільного захисту відповідно до своїх повноважень взаємодіють на підставі завчасно розроблених планів реагування на надзвичайні ситуації [10]. Тобто, зазначеними нормативними документами розроблення плану взаємодії не передбачено.

Відповідно Кодексу цивільного захисту з метою захисту населення і територій від надзвичайних ситуацій у мирний час та в особливий період, забезпечення готовності підпорядкованих сил i засобів до дій, спрямованих на запобігання і реагування на надзвичайні ситуації, відповідні центральні органи виконавчої влади створюють функціональні підсистеми [11].

Крім того, в єдиній державній системі цивільного захисту з метою своєчасного запобігання і ефективного реагування на надзвичайні ситуації організовується взаємодія з питань [9]:

визначення органів управління, які безпосередньо залучаються до ліквідації наслідків надзвичайних ситуацій, складу і кількості сил (засобів) реагування на них;

погодження порядку здійснення спільних дій сил цивільного захисту під час ліквідації наслідків надзвичайних ситуацій 3 визначенням основних завдань, місця, часу i способів їх виконання;

організації управління спільними діями органів управління та сил цивільного захисту під час виконання завдань за призначенням;

всебічного забезпечення спільних заходів, що здійснюватимуться органами управління та підпорядкованими їм силами цивільного захисту, в тому числі взаємного надання допомоги транспортними, інженерними, матеріальними, технічними та іншими засобами.

Залежно від обставин, масштабу, характеру та можливого розвитку надзвичайної ситуації взаємодія організовується: на загальнодержавному рівні - безпосередньо між органами управління та силами функціональних i територіальних підсистем; на регіональному, місцевому та об’єктовому 
рівнях - між територіальними органами центральних органів виконавчої влади, місцевими органами виконавчої влади, їх силами, а також суб'єктами господарювання.

Узагальнюючи положення проаналізованих нормативноправових актів можна зробити такі висновки.

По-перше, формами взаємодії: спільний аналіз обстановки; спільне планування різних дій і заходів; взаємне використання сил і засобів; взаємне інформування зацікавлених суб'єктів; обмін службовим та оперативним досвідом; спільні тренування й заняття та інші, що зумовлені вимогами чинного законодавства.

По-друге, взаємодія здійснюється на різних рівнях міжвідомчому, відомчому.

По-третє, взаємодія має бути багатоваріантною, що обумовлено можливими змінами оперативної обстановки, та передбачає завчасну організацію та постійне підтримання взаємодії за декількома найбільш вірогідними варіантами розвитку ситуації.

По-четверте, до взаємодії висуваються такі вимоги, як стійкість безперервність, гнучкість, цілеспрямованість, активність, прихованість.

По-п'яте, належний рівень взаємодії забезпечується: взаємним знанням покладених завдань, можливостей взаємодіючих суб'єктів, 3'ясуванням і узгодженням різних варіантів дій; систематичним уточненням змісту взаємодії; організацією та підтриманням безперервного зв’язку та постійним взаємним обміном інформацією про обстановку; чітко налагодженими контактами між керівниками взаємодіючих суб'єктів та їх органами управління; належним контролем за дотриманням установленого порядку узгоджених дій.

По-шосте, метою взаємодії $є$ узгодження дій як при виконанні поточних завдань, так i в разі ускладнення оперативної обстановки. 


\section{Науковий вісник: Державне управління № 4(6)2020}

Таким чином, сутність взаємодії полягає в основаних на належній нормативно-правовій регламентації узгоджених на всіх рівнях діях і заходах взаємодіючих суб'єктів під час виконання відповідних завдань.

Розглянемо способи та методи організації взаємодії під час організації та проведення аварійно-рятувальних і невідкладних робіт за етапами виконання завдань.

Організація проведення аварійно-рятувальних і невідкладних робіт включає: прийом і обробку інформації про виникнення надзвичайної ситуації; доведення до підрозділів Оперативно-рятувальної служби цивільного захисту сигналів оповіщення; виїзд і переміщення сил до місця виникнення надзвичайної ситуації; розвідку зони надзвичайної ситуації, зокрема з повітря; розгортання сил і засобів, залучених до ліквідації наслідків надзвичайної ситуації; пошук, рятування постраждалих у зоні надзвичайної ситуації, надання їм домедичної, екстреної психологічної допомоги і підготовку до евакуації в безпечні райони (місця); локалізацію та ліквідацію наслідків надзвичайної ситуації; збір і повернення сил і засобів до місця постійної дислокації [12].

Прийом інформації про надзвичайну ситуацію здійснюється керівником органу управління в найкоротший строк. Відсутність окремих даних не може бути підставою для затримання виїзду підрозділів, якщо відомо місце іiі виникнення. Виїзд і рух до району надзвичайної ситуації здійснюється в найкоротший час, що досягається: швидким збором і виїздом особового складу підрозділу (протягом часу, що не перевищує нормативний) та знанням особовим складом функціональних обов'язків; рухом спеціальної техніки найкоротшим маршрутом із гранично можливою швидкістю; знанням особливостей району виїзду [12].

Під час виконання першого етапу дій (отримання сигналу та пересування до району надзвичайної ситуації) керівник організує взаємодію між підрозділами шляхом віддачі вказівок, в яких уточнює побудову колони, порядок висування, 
швидкість руху, дистанцію між підрозділами та технікою, порядок дій у разі непередбаченої зупинки колони, доводить сигнали управління та оповіщення.

Під час виконання другого етапу дій (проведення розвідки району надзвичайної ситуації та розгортання сил) керівник організує взаємодію між підрозділами, що здійснюють розвідку, щодо напрямів, районів та сил, що залучаються до проведення розвідки, узгоджує питання щодо встановлення небезпечних чинників надзвичайної ситуації, уточнює порядок визначення району (зони) надзвичайної ситуації, виявлення постраждалого населення (які сили, коли i де проводять розвідку, способи використання техніки та обладнання), розподіляе, уточнюе та узгоджує місця розгортання сил цивільного захисту в районі надзвичайної ситуації відповідно до розподілу завдань між ними та спільних дій.

Під час виконання третього етапу дій (пошук, рятування постраждалих у зоні надзвичайної ситуації, надання їм домедичної, екстреної психологічної допомоги і підготовку до евакуації в безпечні місця) організовує, перш за все, пошук і рятування людей, узгоджує дії підрозділів щодо порядку проведення рятувальних робіт, визначає додаткові сили для виконання цього завдання.

Під час виконання третього етапу дій (локалізація та ліквідація наслідків надзвичайної ситуації) організовує та узгоджує дії підрозділів щодо локалізації небезпечних чинників та ліквідації наслідків надзвичайної ситуації, зокрема, уточнює порядок спільних дій підрозділів щодо припинення дії найбільш небезпечних факторів надзвичайної ситуації, зосереджує зусилля підрозділів на головному напрямку.

Під час виконання четвертого етапу дій (збір і повернення сил і засобів до місця постійної дислокації) керівник з'ясовує стан виконання завдань та підрозділів, уточнює послідовність їх повернення до району постійної дислокації, інформує керівника старшої ланки управління про виконання завдань та 
Науковий вісник: Державне управління № 4(6)2020

організовує переміщення підрозділів до пункту постійної дислокації.

Отже, в роботі запропоновано способи та методи організації взаємодії органів управління у процесі ліквідації наслідків надзвичайних ситуацій. Проте, важливим аспектом обрання того чи іншого методу взаємодії $є$ його ефективність та результативність, тобто економічна обгрунтованість.

Загалом управлінське рішення $є$ наслідком дослідження конкретної ситуації, аналізу наявних даних та інформації, прогнозування можливого розвитку подій, здійснення економічного обгрунтування вибору альтернативи із наявних шляхів досягнення конкретної мети. Будь-яке управлінське рішення має ефект від його реалізації, який включає економічну, організаційну, соціальну, юридичну, технологічну складову.

Економічна складова - управлінське рішення щодо обрання конкретного методу взаємодії під час ліквідації наслідків надзвичайних ситуацій має певну вартість, тобто вимагає фінансових та матеріальних вкладень. Оскільки наслідки надзвичайних ситуацій зазвичай фінансуються 3 Державного та/або місцевих бюджетів, то обрання економічноефективного методу взаємодії $\epsilon$ надзвичайно важливим. Організаційна - ухвалене рішення повинно бути підкріплене зрозумілими механізмами його реалізації, відпрацьованою системою контролю, а також вертикальною координацією робіт, спрямованих на подолання наслідків надзвичайних ситуацій. Соціальна - полягає у обранні методу взаємодії, який максимально враховуватиме інтереси суспільства, наприклад населення, яке знаходиться в зоні надзвичайної ситуації тощо. Юридична - передбачає наявність юридичних підстав для застосування обраного методу взаємодії, тобто ухвалюючи рішення має бути враховано як вітчизняне нормативноправове поле, так й положення міжнародних нормативноправових актів у цій сфері. Технологічна - наявність технологічних та інформаційних ресурсів для реалізації 
Науковий вісник: Державне управління № 4(6)2020

управлінського рішення щодо застосування того чи іншого методу взаємодії.

Економічне обгрунтування забезпечує максимально позитивний економічний ефект від прийнятого управлінського рішення. Економічне обгрунтування передбачає здійснення фінансово-економічного аналізу. Базовою концепцією фінансово-економічного аналізу $є$ концепція альтернативної вартості, яка передбачає декілька варіантів використання обмежених ресурсів держави, їх вартість повинна розглядатися з погляду втраченої можливості прийняття більш ефективного та результативного управлінського рішення із застосуванням наявних ресурсів.

Поняття ефективності визначається як співвідношення між досягнутими результатами прийняття управлінського рішення та використаними ресурсами.

Результативність - міра досягнення поставлених цілей, очікуваних результатів. Досягнення визначених цілей задля досягнення яких приймається управлінське рішення is використанням мінімальних ресурсів належної якості характеризує категорію економічності.

Метою фінансово-економічного аналізу управлінського рішення $\epsilon$ встановлення його соціальної результативності, вплив на національний рівень добробуту країни, економічної ефективності на підставі альтернативної вартості ресурсів, які використовуються при реалізації рішення, його технологічний і юридичний ефект.

Виокремлюємо такі види фінансово-економічного аналізу методів взаємодії органів управління при надзвичайних ситуаціях:

горизонтальний аналіз полягає в порівнянні застосування окремих методів шляхом зіставлення їх застосування в динаміці при минулих надзвичайних ситуаціях. Визначення позитивних та негативних наслідків даного методу в конкретній надзвичайній ситуації, що надасть можливість 
Науковий вісник: Державне управління № 4(6)2020

обгрунтувати ефективність методу при певному виді надзвичайної ситуації;

вертикальний аналіз - аналіз результативності виконання задач з ліквідації наслідків надзвичайних ситуацій на рівні окремого органу управління на відповідному рівні (державному чи місцевому);

аналіз відносних показників - розрахунок відношень між отриманим результатом та витраченими фінансовими i матеріальними ресурсами.

факторний аналіз - визначення конкретних факторів впливу обраного методу на досягнення кінцевого результату (ліквідації наслідків надзвичайних ситуацій) і таким чином, встановлення його ефективності. При цьому факторний аналіз може бути як прямим (власне аналіз), коли результативний показник розділяють на окремі складові, так і зворотним (синтез), коли його окремі елементи з'єднують у загальний результативний показник.

За глибиною аналітичного дослідження виділяється повний і тематичний фінансовий-економічний аналіз. Повний проводиться 3 метою вивчення всіх аспектів реалізації конкретного методу взаємодії органів управління. Тематичний - за окремим обраним аспектом реалізації обраного методу.

За об’єктом фінансово-економічного аналізу виділяють такі його види:

аналіз застосування певного методу взаємодії на державному рівні в цілому;

на рівні окремих підрозділів, наприклад органів місцевого самоврядування.

Ефективність фінансово-економічного аналізу визначається різними факторами. Основними рекомендаціями задля досягнення максимальної ефективності такого аналізу є: розробка чіткої програми фінансово-економічного аналізу, включаючи форми аналітичних таблиць, алгоритмів розрахунку основних показників i необхідних для їх 
розрахунку і порівняльної оцінки джерел інформаційного і нормативного забезпечення; схема аналізу повинна бути побудована за допомогою дедуктивного методу пізнання; відхилення від нормативних чи планових значень показників, повинні підлягати ретельному дослідженню. Сутність останньої рекомендації сприятиме виявленню основних факторів, що викликали зафіксовані відхилення від заданих орієнтирів та належному рівню обгрунтованості прийнятої системи планування їі лабільності.

Також, важливо враховувати, що завершеність і цілісність будь-якого аналізу, що має економічну спрямованість, у значній мірі визначаються обгрунтованістю використовуваної сукупності критеріїв. Як правило, ця сукупність включає якісні i кількісні оцінки, однак іï основу за звичай складають показники, що мають зрозумілу інтерпретацію i, по можливості, певні орієнтири (границі, нормативи, тенденції). Крім того, потрібно пам'ятати, що разовий фінансовоекономічний аналіз, не дає повної впевненості у ефективності обраного методу взаємодії органів управління в умовах кризового управління, оскільки задля високоточного фінансово-економічного обгрунтування того чи іншого методу важливе дослідження їх застосування за умов минулих надзвичайних подій задля виявлення тенденцій i закономірностей.

На отриманні результати фінансово-економічного аналізу впливають також достовірність та повнота аналізованої інформації. Проте ціль здійснення такого аналізу не змінна виявлення можливостей підвищення ефективності застосування конкретного методу взаємодії в окремій надзвичайній ситуації.

Зазначені вище умови є факторами. Фактор - це причина, рушійна сила будь-якого процесу, що визначає його характер або окремі його риси. Фактори, що впливають на управлінське рішення (ризик-фактори), - це процеси та / або рушійні сили, які безпосередньо змінюють очікуваний результат від 
прийнятого управлінського рішення. Ризик-фактори можна поділити на зовнішні та внутрішні. Зовнішні фактори - це в основному неконтрольовані сили, які впливають на реалізацію управлінського рішення, проте орган управління не має змоги відкоригувати їх вплив. Внутрішніми $\epsilon$ фактори, які утворюються в межах органу управління i управлінець за допомогою певних важелів в змозі змінити їх вплив.

Дослідження факторів, що впливають на окремі процеси базується на ризикоорієнтованому підході. Ризикоорієнтований підхід передбачає виявлення факторів, які негативно можуть вплинути на реалізацію прийнятого управлінського рішення, тобто не забезпечити досягнення очікуваних результатів. Застосування даного підходу у фінансово-економічному аналізі нині $€$ надзвичайно актуальним у зв'язку 3 непростою ситуацією в країні та режимом посиленої економії бюджетних коштів, а також обмеженими часовими рамками в умовах кризового управління.

За рахунок застосування ризикоорієнтованого підходу можна попередити або знизити ймовірність прийняття неефективного, не результативного i неекономічного управлінського рішення, що супроводжуватиметься нецільовим використанням бюджетних коштів.

Факторний аналіз $є$ також методом економічного та фінансового аналізу. Його ще називають класичним методом аналізу, який поділяється на методи: ланцюгових підстановок, арифметичних різниць, балансовий, виділення ізольованого впливу факторів, процентних чисел, диференціальний, логарифмічний, інтегральний, простих і складних процентів. У рамках фінансового менеджменту ці методи використовуються головним чином для оцінки і прогнозування фінансового стану підприємства, а також виділення основних факторів його покращення.

Також у економічній теорії та практиці існують інші методи економічного та фінансового аналізу. Зокрема, 


\section{Науковий вісник: Державне управління № 4(6)2020}

традиційні методи економічної статистики: середніх і відносних величин, групування, графічний, індексний, елементарні методи обробки рядів динаміки. Ці методи широко використовуються в фінансовому менеджменті. Математико-статистичні методи вивчення зв'язків: кореляційний аналіз, регресійний аналіз, дисперсійний аналіз, сучасний факторний аналіз, дискримінантний аналіз, метод головних компонент, коваріаційний аналіз, метод об’єктоперіодів, кластерный аналіз та ін. Таким чином, у ході аналізу фінансового стану підприємства можуть використовуватися найрізноманітніші прийоми, методи і моделі аналізу. Їхня кількість та широта застосування залежать від цілей аналізу та визначаються його завданням в кожному випадку. Для здійснення економічного обгрунтування управлінських рішень щодо взаємодії за будь-яким із методів фінансово-економічного аналізу застосовуються кількісні та якісні показники, які включають систему розрахунків. За результатами таких розрахунків визначається найбільш ефективний, результативний та економічний метод взаємодії за умов виникнення певного виду надзвичайної ситуації. Оскільки в умовах кризового управління часові рамки обмежені, важливо, щоб аналіз здійснювався на підставі наявного досвіду управління при надзвичайних ситуаціях, які мали місце як в Україні, так і за іiі межами.

Висновки. За результатами дослідження розроблено пропозиції щодо удосконалення правового, організаційного та економічного забезпечення процесу організації взаємодії між органами управління в умовах надзвичайних ситуацій.

Правове забезпечення організації взаємодії пропонується удосконалити шляхом внесення доповнень у Кодекс цивільного захисту України, де окремою статтею глави 15. “Організація робіт 3 реагування на надзвичайні ситуації” включити завдання щодо організації взаємодії між органами управління в умовах надзвичайних ситуацій. 
Науковий вісник: Державне управління № 4(6)2020

Організаційне забезпечення організації взаємодії пропонується удосконалити шляхом:

встановлення послідовності дій та прийняття рішення керівників і посадових осіб органів управління, питання організації взаємодії застосовуючи найбільш раціональні методи, що відповідають умовам конкретної надзвичайної ситуації;

визначення основним способом організації взаємодії, а саме: розподіл та узгодження дій між підрозділами 3 метою досягнення розуміння кожним керівником послідовності виконання спільних дій за етапами дій;

організації роботи органів управління у надзвичайних ситуаціях щодо організації взаємодії за режимами та методами: у режимі повсякденного функціонування та підвищеної готовності - методом розгляду сценаріїв розвитку надзвичайної ситуації та заслуховування порядку спільних дій керівників нижчої ланки управління; у режимі надзвичайної ситуації та надзвичайного стану - методом вказівок та поєднання вказаних методів.

Економічне забезпечення організації взаємодії запропоновано здійснювати шляхом економічного обгрунтування управлінських рішень щодо взаємодії між органами управління за будь-яким із методів фінансовоекономічного аналізу, застосування кількісних та якісних показників, що включають систему розрахунків. За результатами таких розрахунків визначати найбільш ефективний, результативний та економічний метод організації взаємодії 3 урахуванням особливостей конкретної надзвичайної ситуації.

\section{Список використаних джерел}

1. Бакуменко В. Д. Прийняття рішень в державному управлінні. Ч. 1. Теоретико-методологічні засади: навч. посіб. / ВПЦ АМУ. Київ, 2010. С. 107-113.

2. Волянський П. Б. Принципи взаємодії сил цивільного захисту в міжнародних гуманітарних операціях 3 ліквідації медикосанітарних наслідків надзвичайних ситуацій. Державне 


\section{Науковий вісник: Державне управління № 4(6)2020}

управління: удосконалення та розвиток: електрон. наук. фах. вид. / Дніпров. держ. аграрно-екон. ун-т. 2013. № 3. URL : http://www.dy.nayka.com.ua/?op=1\&z=588 (дата звернення: 31.10.2020).

3. Терент'єва А. В. Управління надзвичайними ситуаціями 3 елементами кризового менеджменту. Державне управління: удосконалення та розвиток : електр. наук. фах. вид. / Дніпров. держ. аграрн.-економ. ун-т. 2015. № 9. URL : http://www.dy.nayka.com.ua/?op $=1 \& \mathrm{z}=881$ (дата звернення: 31.10.2020).

4. Changwon Son, Farzan Sasangohar, Timothy J. Neville, S. Camille Peres, Jukrin Moon Evaluation of work-as-done in information management of multidisciplinary incident management teams via Interaction Episode Analysis, Elsevier, 04.2020. URL : https://www.sciencedirect.com/science/article/abs/pii/S000368701930 2388. (дата звернення: 26.10.2020).

5. Дерев'янко О. В., Юрченко В. О. Організація взаємодії між органами управління та силами цивільного захисту - ключове питання управління у надзвичайних ситуаціях. Наукове забезпечення освітньої діяльності у сфері иивільного захисту / Матеріали наук.-практ. конф. (19 трав. 2019 м. Київ). Київ : ІДУЦЗ, 2019. 142 с.

6. Кульшай Ю. В., Юрченко В. О. Деякі питання організації взаємодії між органами влади та силами цивільного захисту в умовах воєнного конфлікту. Наукове забезпечення освітньої діяльності у сфері иивільного захисту / Матеріали наук.-практ. конф. (19 трав. 2019 м. Київ). (19 трав. 2019 м. Київ), - Київ : ІДУЦЗ, 2019. 142 с.

7. Кулєшов М. М., Ларін О. М. Удосконалення системи взаємодії під час ліквідації наслідків надзвичайних ситуацій. Проблеми надзвичайних ситуацій: Зб. наук. пр. Вип. 8, 2008. НУЦЗУ. C. 103-108.

8. Інформаційно-аналітична довідка про надзвичайні ситуації в Україні, що сталися впродовж 2019 року / Вебсайт ДСНС / ДСНС. URL: https://www.dsns.gov.ua/ua/Dovidka-zakvartal/110733.html. (дата звернення: 26.10.2020).

9. Про затвердження Положення про єдину державну систему цивільного захисту : постанова Кабінету Міністрів України від 9.01.2014 № 11 // База даних “Законодавство України” / ВР України. URL : https://zakon.rada.gov.ua/laws/show/11-2014$\% \mathrm{D} 0 \% \mathrm{BF}$ स $\mathrm{Text}$ (дата звернення 26.10.2020).

10. Про затвердження Плану реагування на надзвичайні ситуації державного рівня : постанова Кабінету Міністрів України від 
14.03.2018 № 223 // База даних “Законодавство України” / ВР України. URL : https://zakon.rada.gov.ua/laws/show/223-2018$\% \mathrm{D} 0 \% \mathrm{BF} \#$ Text (дата звернення 26.10.2020).

11. Кодекс цивільного захисту України: Закон України від 2.10.2012 № 5403-VI // База даних “Законодавство України” / ВР України. https://zakon.rada.gov.ua/laws/show/5403-17\#Text : (дата звернення: 26.10.2020).

12. Про затвердження Статуту дій у надзвичайних ситуаціях органів управління та підрозділів Оперативно-рятувальної служби цивільного захисту та Статуту дій органів управління та підрозділів Оперативно-рятувальної служби цивільного захисту під час гасіння пожеж : наказ МВС України від 26.04.2018 № 340 // База даних "Законодавство України" / BP України. URL : https://zakon.rada.gov.ua/laws/show/z0801-18\#Text (дата звернення 26.10.2020).

\section{References}

1. Bakumenko, V. D. (2010). Pryiniattia rishen v derzhavnomu upravlinni. [Decision making in public administration]. (Vols. 1). Kyiv: VPTs AMU [in Ukrainian].

2. Volianskyi, P. B. (2013). Pryntsypy vzaiemodii syl tsyvilnoho zakhystu $\mathrm{v}$ mizhnarodnykh humanitarnykh operatsiiakh z likvidatsii medyko-sanitarnykh naslidkiv nadzvychainykh sytuatsii. [Principles of interaction of civil defense forces in international humanitarian operations to eliminate the health consequences of emergencies]. Derzhavne upravlinnia: udoskonalennia ta rozvytok - Public administration: improvement and development, 3. URL : http://www.dy.nayka.com.ua/?op=1\&z=588. [in Ukrainian].

3. Terentieva, A. V. (2015) Upravlinnia nadzvychainymy sytuatsiiamy $z$ elementamy kryzovoho menedzhmentu. [Emergency management with elements of crisis management]. Derzhavne upravlinnia: udoskonalennia ta rozvytok - Public administration: improvement and development, $9 . \quad$ URL : http://www.dy.nayka.com.ua/?op=1\&z=881 [in Ukrainian].

4. Changwon Son, Farzan Sasangohar, Timothy J. Neville, S. Camille Peres \& Jukrin Moon (2020) Evaluation of work-as-done in information management of multidisciplinary incident management teams via Interaction Episode Analysis, Elsevier, 04.2020. www.sciencedirect.com URL : https://cutt.ly/BhehkUT [in English].

5. Derevianko, O. V. \& Yurchenko, V. O. (2019) Orhanizatsiia vzaiemodii mizh orhanamy upravlinnia ta sylamy tsyvilnoho zakhystu - kliuchove pytannia upravlinnia $\mathrm{u}$ nadzvychainykh 
sytuatsiiakh [The organization of interaction between the governing bodies and the civil defense forces is a key issue of emergency management]. Proceedings from: Nauk.-prakt. konf. "Naukove zabezpechennia osvitnoi diialnosti u sferi tsyvilnoho zakhystu" Scientific and Practical Conference "Scientific support of educational activities in the field of civil protection". Kyiv : IDUTsZ [in Ukrainian].

6. Kulshai, Yu.V. \& Yurchenko, V. O. (2019) Deiaki pytannia orhanizatsii vzaiemodii mizh orhanamy vlady ta sylamy tsyvilnoho zakhystu $\mathrm{V}$ umovakh voiennoho konfliktu [Some issues of organization of interaction between the authorities and civil defense forces in the context of military conflict] Proceedings from: Nauk. prakt. konf. "Naukove zabezpechennia osvitnoi diialnosti u sferi tsyvilnoho zakhystu" - Scientific and Practical Conference "Scientific support of educational activities in the field of civil protection”. Kyiv : IDUTsZ [in Ukrainian].

7. Kulieshov, M.M. \& Larin, O.M. (2008) Udoskonalennia systemy vzaiemodii pid chas likvidatsii naslidkiv nadzvychainykh sytuatsii. [Improving the system of interaction during the elimination of the consequences of emergencies]. Problemy nadzvychainykh sytuatsii Problems of emergencies, 8. (pp. 103-108). NUTsZU [in Ukrainian].

8. Informatsiino-analitychna dovidka pro nadzvychaini sytuatsii v Ukraini, shcho stalysia vprodovzh 2019 roku [Information and analytical report on emergencies in Ukraine that occurred during 2019]. (n.d.) www.dsns.gov.ua Retrieved from https://www.dsns.gov.ua/ua/Dovidka-za-kvartal/110733.html [in Ukrainian].

9. Postanova Kabinetu Ministriv Ukrainy "Pro zatverdzhennia Polozhennia pro yedynu derzhavnu systemu tsyvilnoho zakhystu" vid 09.01.2014 № 11. [Decree of the Cabinet of Ministers of Ukraine "On approval of the Regulation on the unified state system of civil protection" from January 9, 2014 № 11] (n.d.) zakon.rada.gov.ua URL : https://zakon.rada.gov.ua/laws/show/11-2014-\%D0\%BF\#Text [in Ukrainian].

10. Postanova Kabinetu Ministriv Ukrainy "Pro zatverdzhennia Planu reahuvannia na nadzvychaini sytuatsii derzhavnoho rivnia" vid 14.03.2018 № 223. [Decree of the Cabinet of Ministers of Ukraine "On approval of the State-level emergency response plan" from March 14, 2018 № 223] (n.d.) zakon.rada.gov.ua URL : https://zakon.rada.gov.ua/laws/show/223-2018-\%D0\%BF\#Text [in Ukrainian].

11. Zakon Ukrainy "Kodeks tsyvilnoho zakhystu Ukrainy" vid 02.10.2012 № 5403-VI. [Law of Ukraine "Code of Civil Protection of Ukraine" from October 2, 2012 № 5403-VI] (n.d.) 
zakon.rada.gov.ua URL : https://zakon.rada.gov.ua/laws/show/540317\#Text [in Ukrainian].

12. Nakaz Ministerstva vnutrishnikh sprav Ukrainy "Pro zatverdzhennia Statutu dii u nadzvychainykh sytuatsiiakh orhaniv upravlinnia ta pidrozdiliv Operatyvno-riatuvalnoi sluzhby tsyvilnoho zakhystu ta Statutu dii orhaniv upravlinnia ta pidrozdiliv Operatyvno-riatuvalnoi sluzhby tsyvilnoho zakhystu pid chas hasinnia pozhezh" vid 26.04.2018 № 340. [Order of the Ministry of Interior of Ukraine "About approval of the Charter of actions in emergency situations of management bodies and divisions of Operational rescue service of civil protection and the Charter of actions of management bodies and divisions of Operational rescue service of civil protection during fire extinguishing” from april 26, 2018 № 340]. (n.d.) zakon.rada.gov.ua. URL : https://zakon.rada.gov.ua/laws/show/z0801-18\#Text. [in Ukrainian].

\section{INTERACTION'S ORGANIZATION BETWEEN GOVERNING BODIES IN EMERGENCY SITUATIONS: LEGAL, ORGANIZATIONAL AND ECONOMIC ASPECTS}

Bielikova Kseniia, Cand. Cs. (Eng.), SRF, Senior Research Worker of the Research Department, Institute of Public Administration and Research in Civil Protection, Kyiv, tel. : +380996370993, e-mail: acutus@ukr.net, https://orcid.org/0000-0001-7475-2115

Kravchenko Yuliia, Cand. Cs. (Econ.), Associate Professor of the Department of Public Administration in the sphere of civil protection, Institute of Public Administration and Research in Civil Protection, Kyiv, tel. : +380979644539, e-mail: kravchenko-yulia@ukr.net, https://orcid.org/0000$\underline{0002-3709-7016}$

Poteriaiko Sergii, Cand. Cs. (Mil.), Assoc. Prof., Deputy Chief of the Research Department, Institute of Public Administration and Research in Civil Protection, Kyiv, tel. : +380934653432, e-mail: sergiy_kiev@ukr.net , https://orcid.org/0000-0002-3787-0929

Marchenko Alexandr, Cand. Cs. (Mil.), Assoc. Prof., Assoc. Prof. of the Department of the Land Forces of the Command-and-Staff Institute of the Troops (Forces) Combat Use, The National Defense University of Ukraine named after Ivan Cherniakhovskyi, Kyiv, + tel. : 380997724071, e-mail: martcello@i.ua, https://orcid.org/0000-0002-5189-3254

Abstract. The significant number and large-scale consequences of emergency situation occurring in the world, that leading to irreversible losses, have 
Науковий вісник: Державне управління № 4(6)2020

identified the area of many scientist's research interest. They investigate the causes of unforeseen events in order to prevent them, measures to respond to them by relevant services, the effectiveness of emergency response, both natural and man-made, and so on. Rational interaction between the governing bodies and the forces involved in the dealing with an emergency is important in the emergency response. After all, people's lives depend on the coherence of such interaction, timely adjustment of actions of these bodies and forces, that basis of relevant information. Current legal, organizational and economic aspects of interaction's organization between government bodies in emergency situations have become the subject of research by the author's team. The article notes measures to improve the process of organizing interaction, based on the obtained scientific author's results. Improvement of legal support provides for additions to the Code of Civil Protection of Ukraine in terms of the interaction's organization between government bodies. The choice of a rational method of organizing interaction that meets the conditions of a particular emergency determines the organizational aspect. Economic component involves the use of a rational method of financial and economic analysis, which allows to determine the most effective, efficient and economical method of interaction.

Key words: emergency situation, methods of interaction, governing bodies, economic substantiation, administrative decision, financial and economic analysis 